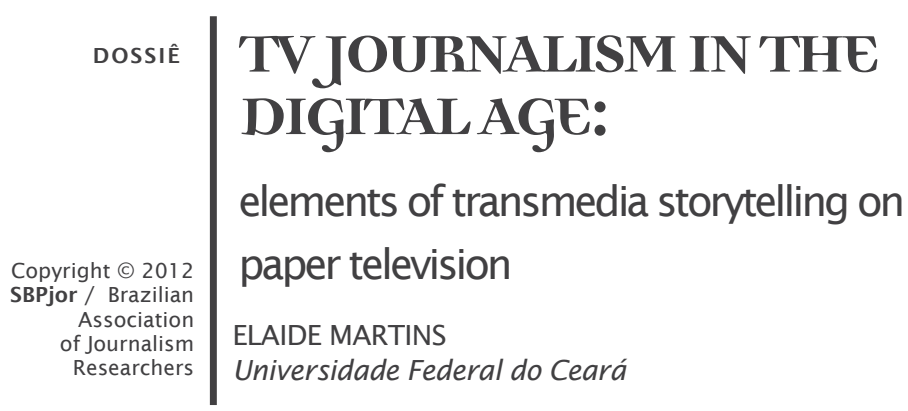

\begin{abstract}
This paper proposes a reflection on audiovisual journalism from the perspective of transmedia storytelling (NT), a term coined by Henry Jenkins (2009a) in his research on the culture of convergence. How has media convergence affected the language and aesthetics of audiovisual journalism? And what of the routine and profile of its professionals? Or the relationship with the audience? What are the new paradigms and what has changed in their production processes as regards the use of new media? To reflect on these and other issues, it is necessary to identify and analyze aspects of transmedia storytelling on TV Folha, an audiovisual program inspired by printing, which began as a private channel on the web and is today shown by a public broadcaster. It is a product which seems to indicate that transmedia storytelling is beginning to establish a firm place in Brazilian audiovisual journalism based on its relationship with new information platforms.
\end{abstract}

Keywords: Journalism. Broadcast journalism. Convergence. Transmedia storytelling.

\title{
TELEJORNALISMO NA ERA DIGITAL: aspectos da narrativa transmídia na televisão de papel
}

RESUMO - O presente artigo propõe uma reflexão sobre o jornalismo audiovisual a partir da perspectiva da narrativa transmídia (NT), termo cunhado por Henry Jenkins (2009a) em suas pesquisas sobre a cultura da convergência. Como a convergência midiática vem afetando a linguagem e a estética do jornalismo audiovisual? E a rotina e perfil de seus profissionais? E a relação com a audiência? Quais os novos paradigmas e o que mudou em seus processos produtivos com o uso das novas mídias? A fim de refletir sobre essase outras questões, procuramos identificar e analisar aspectos da narrativa transmídia na TV Folha, um programa audiovisual inspirado no impresso, que nasceu como um canal privado na web e hoje é exibido por uma emissora pública; um produto que nos leva a crer que a narrativa transmídia começa a firmar o seu espaço no jornalismo audiovisual brasileiro a partir da relação deste com as novas plataformas de informação.

Palavras-chave: Jornalismo. Telejornalismo. Convergência.Narrativa transmídia.

\section{TELEPERIODISMO EN LA ERA DIGITAL:} aspectos de la narrativa transmedia en la televisión de papel

RESUMEN - El presente artículo propone una reflexión sobre el periodismo audiovisual a partir de la perspectiva de la narrativa transmedia (NT), término acuñado por Henry Jerkins (2009a) en sus investigaciones sobre la cultura de la convergencia. ¿Cómo está afectando la convergencia mediática al lenguaje y a la estética del periodismo audiovisual? ¿Y a la rutina y al perfil de sus profesionales? ¿Y a la relación con su audiencia? ¿Cuáles son los nuevos paradigmas y qué ha cambiado en sus procesos productivos con el uso de nuevos canales y soportes audiovisuales? Con el objetivo de reflexionar sobre estas y otras cuestiones, identificamos y analizamos aspectos de la NT en TV Folha, un programa audiovisual inspirado en el impreso, que nació como un canal privado en la Red y que hoy se presenta en una cadena pública. Se trata, pues, de un producto que nos lleva a pensar que la NT empieza a consolidarse en el periodismo audiovisual brasileño a partir de su relación con las nuevas plataformas de información.

Palabras clave: Periodismo. Teleperiodismo. Convergencia. Narrativa transmedia 


\section{Introduction}

Since it was officially introduced in Brazil in September 1950, television and, consequently, TV journalism, have experienced new languages, formats, models and narratives. The history of the former shows that certain technological innovations have marked its evolution, such as the use of videotape, satellite, color, cable transmission and, more recently, the internet.

The polarization of television, initially characterized by the opposition between public TV and private TV, gave way to the emergence of open and closed TV, analog TV and digital TV, online TV and the socalled traditional TV. The programming, already segmented with the appearance of cable TV (closed), became even more specialized with the development of cyber TV - a type of online TV whose channels are produced and broadcast exclusively on the internet (AMARAL, 2007), representing one of the products of convergence culture. The audience plays a key role within this landmark context, by altering relationships and processes.

Digital technologies have transformed the way of watching and making television, enabling viewers to watch it in its various media forms: from the internet to cell phones, from car stereos to GPSs. These are new media that can be classified, as the Canadian Marshall McLuhan advances, as "extensions of ourselves". Television now accompanies the viewer who, in turn, can collaborate, comment, share opinions and messages, due to horizontal interactivity provided by the internet.

This active participation of the audience represents the current, major transformation. Therefore, rather than representing the result of significant technological developments that have accrued over the years, the so-called "digital age" alters profoundly social relations, by doing journalism, unveiling new languages, models and narratives. In this context, transmedia storytelling (NT) expands the possibilities of audiovisual journalism, allowing the public to participate, for instance through the production of certain news from their relationship with the new information platforms. But is this narrative already present in Brazilian television journalism?

To answer this question, this article undertakes a case study of the Sunday program TV Folha, focusing on the issues discussed from the second Sunday of March through to July 2012, in addition to conducting a general survey of all the reports displayed since its inception, from 
March 11, 2012 until September 12, 2012. However, before conducting this analysis, it is necessary to discuss the literature on NT in the country.

\section{An outline of the approaches to transmedia storytelling in Brazil}

Transmedia storytelling has emerged as a result of the development of convergence culture, in response to media convergence, meeting consumers' needs and depending on the active participation of knowledge communities (JENKINS, 2009a). Thus, the NT is referred to as "the art of creating a universe." In case an interconnected universe in different communication channels, whose meaning is only fully understood when the content is experienced fully, viewed from all angles.

Jenkins (2009a) explains that the transmedia scenario establishes itself as a narrative passes from one medium to another, constructed independently, allowing the public to understand it - in all media. Therefore, the transmedia relationship lies in the relationship between stories, linked by a single plot, but narrated and transmitted by independent means. This is a scenario that arguably can already be identified in Brazilian television news broadcasting.

Research on transmedia storytelling in Brazil is recent. It probably began to take shape in the second half of the 2000s but without adopting the term "transmedia". Media analyst Geoffrey Long discussed the concept in 2009 (apud TAVARES, 2009) at an event in Rio de Janeiro sponsored by the Advanced Education Center (Nave)i, capturing the Brazilian audience. The interest generated an interviewii in which Long discussed the use of NT in education and fiction.

In the academic world, approaches began with fictional products. Bieging, Busarello and Ulbricht (2010) put forward the transmedia scenario as a new era of cultural industry, expanding its market niche through media convergence, since industries "can thus attract potential new customers. Each medium has its share of audience, which through transmedia storytelling, can be won over in some way" (BIEGING; BUSARELLO; ULBRICHT, 2010, p. 4). Regarding the applicability of NT in journalism, Souza and Mielniczuk (2010, p.1) argue that: "it is possible to confirm that, in the digital environment, aspects of narrative used in entertainment products in a context Jenkins (2009a) has termed culture of convergence, also appear as resources of journalism storytelling."

This was reinforced by the director of Starlight Runner, Jeff Gomez (apud DÓRIA 2010), during a lecture on Rede Globo, in February 2010, who admitted the possibility of adopting the model of NT for journalism. 
Dória (2010) describes his virtual participation in this event, explaining that, upon addressing the speaker, he got the following answer:

\begin{abstract}
Yes. I was recently consulted by Turner and much of what I said concerned especially CNN on the theme of journalism. The essence is the ability to convert stories in a way that will make you wait for the commercial to see what happens and even to take action [...] But I think the main thing that can help is to allow for closer dialogue between the viewer and the journalist, and the media company. When there is dialogue, it is easier to make changes. (GOMEZ apud DÓRIA, 2010, online).
\end{abstract}

Pernisa Júnior (2010) explores the possibility of a concept of journalism following the same idea proposed by Jenkins (2009a) on the $\mathrm{NT}$, warning of the need not to confuse it with a simplistic view of media convergence. Further, the author (2010) subscribes to the 'open monad' proposal, involving blocks of information relating to an overall theme that could cause binding through linkage, and be used "both on the web and within this framework of transmedia journalism, with several vehicles participating in the construction of the story" (PERNISA JR, 2010, p. 7), "generating a structure, a composite textuality" (PERNISA JR and ALVES, 2010, p. 71). On internet news portals, it is possible to identify this structure but as the author states, the concepts of transmedia and convergence should not be confused.

Martins (2011), in turn, draws a conceptual and empirical distinction between cross-mediaiii and transmedia storytelling, discussing the applicability of both in web journalism. The author justifies the need to distinguish these concepts because they are still used in a confusing way and even equivalent to the concept of convergence in an imprecise and comprehensive way.

This is because the meanings are similar. But this study adopts the conception proposed by Jenkins (2009a), for whom convergence takes on multiple communication channels from the interactivity between them, relating to the way in which information is received, processed and re-designed by the public. Along the way, interaction is critical since, as the author explains, the collective process becomes part of the consumer, having to assimilate the convergence from the interconnected relationship that people might have with the new media. Therefore, convergence is a cultural process.

By convergence, I mean the flow of content from multiple media platforms, the cooperation between multiple media markets and the migratory behavior of media audiences, going almost anywhere in search of the entertainment experiences they want. (JENKINS, 2009a, p. 29). 
This new scenario thus broadens the possibilities for transmedia storytelling appropriation by television news broadcasting. In this field, convergence has implications that go beyond languages, formats and media, affecting the skills of journalists (due to the emergence of a new professional profile), their productive routines, and appealing to audiences, who enjoy the power to choose what media to use, what programs they watch, and when and how to watch them (fully or partially).

By submitting questions and reflections about how the NT could be used in journalism, Diniz (2011, p.10) points out that: "although Brazilian publications on this subject are few, the researchers dealing with the issue agree on the possibility of transmedia storytelling being used in journalism." The author explains that in addition to researchers, practitioners also agree "on the viability of that, given the characteristics of journalism today, which is open to public participation and convergent both in terms of content and media" (Diniz, 2011, p. 1).

Regarding the particulars of NT in journalism, the research carried out by Souza (2011) raises reflections on the use of different platforms and content formats, as well as on active audience participation in the preparation of interviews and the recommendation of the narrative passages thereof. Souza's study represents important progress in the field not only because it overcomes the theoretical-conceptual approach, but also since it establishes a link between theory and practice.

This study aims to contribute by analyzing, with reference to TV Folha, the appropriation of the principles of transmedia storytelling as systematized by Jenkins (2009b) in the fictional universe and adopted by Souza (2011) in his research on the understanding arrived at, based on certain journalism-oriented observation operators. Despite the limitations imposed by the format of an article, this study offers a valuable contribution in seeking to identify and analyze the key concepts of NT in an essentially converging product: TV Folha, made up of topics, editorials, teams and equipment from the printed format, the internet and broadcast TV - a product herein called "paper television".

\section{Elements of transmedia storytelling on paper television}

TV Folha already existed on the UOL news and Folha.com websites. It also acquired a Facebook page (released on August 3, 2011) when it started being aired on TV Cultura, of São Paulo, on March 11, 2012. It is a rare example of cyber TV featuring on broadcast (and public) television in Brazil. Occupying half an hour of the station's Sunday grid, 
the program starts at $7.30 \mathrm{pm}$ and is broadcast in real time by UOL and Folha.com, and then made available on demandiv (bit-stream in the first week and then in modules), as well as on the TV Cultura website. Being a product of a private communication vehicle shown via a public broadcaster, TV Folha faced reactions, criticisms and questions from the audience. On the other hand, it was praised and considered a qualified entertainment alternative, creating controversy that resulted in a public hearing at the State Legislative Assembly of São Paulov

Part of this controversy can be attributed to the fact that the editorial content is the sole responsibility of Folha de São Paulo (FSP), making TV Cultura a mere broadcaster. Moreover, this "public-private partnership" occurs in an election year, when vested interests may be at play but unapparent. The controversies were raised in forums, on blogs and websites in general, such as the Press Observatory or National Forum for Democratization of Communication, websites.

According to the executive editor of FSP, Sérgio D'Ávila (apud CARVALHO, 2012, online), "Folha has expanded the platforms on which it operates - and in some of these, it is already a leader, for instance in the digital world, on tablets and social networks. In this context, making it to TV was the next, natural step." In an interview for Jornal propaganda e Marketing, the superintendent of Grupo Folha, Antonio Mendes (apud DORES, 2012), stated that the invitation came from TV Cultura, which would also have invited other groups to make up its broadcasting grid but, by September 2012, only FSP had aired its program.

\footnotetext{
Cultura invited us and Abril and Estado to form a partnership in which we could occupy a certain space on the channel, and organize an exchange of pages for minutes on TV. We have 30 minutes on Cultura. In return, we would provide the equivalent of 30 minutes of paper in newspaper ads. (MENDES apud DORES, 2012, online).
}

Comprising three blocks, the program uses the language of FSP as the setting for presenters and columnists, such as Clovis Rossi, Xico Sá, Bárbara Gancia, among others who also write in the printed version. Reports are produced by professionals in the newsrooms of São Paulo, Rio de Janeiro and Brasilia, in addition to national and international correspondents. Images are provided by FSP photographers, who use the same cameras as those in the printed version. The director of TV Folha, John Wainer (apud KACHANI, 2012), highlights the versatility and advantages of the SLR digital camera, the resolution of which is higher than that of film cameras generally used in broadcast television: "This equipment, which is more compact and cheaper, is revolutionizing the 
market, it has been used on the TV series House and in parts of the movie Black Swan" (WAINER, 2012 apud KACHANI, 2012, online). Regarding the work of reporters, he adds, the idea is to create a counterpoint to conventional television journalism by adopting little off narration and a new language.

On TV Folha, the reporter does not appear with the microphone in their hands, describing the news didactically. They might appear in the newspaper newsroom, in the studio of TV Folha or on some footage recorded outdoors, with no makeup, and talk without even looking at the camera. (WAINER apud KACHANI, 2012, online).

Another difference in the language adopted by TV Folha is borne out in the editing, which is carried out dynamically, alternating moving images with images, graphics and arts, well in the FSP style. The sound is also remarkable. These elements give the program's reports an aesthetic quality resembling documentaries. "The script is freer. So is the use of soundtrack. And the images are amazing, closer than those on the internet or television" (WAINER apud KACHANI, 2012).

At its virtual address (www.folha.com.br/tv), the program allows for interaction with the audience, who can: follow it through social networks such as Facebook and Twitter, recommend, comment and share the links of reports and/or send them by email, increase or decrease font size in the text, report errors, copy the link and print the text. There is also a comments section where users can post opinions, praise, criticize and/or share the reports. Users can also reply to comments (building a discussion forum), vote to indicate that they "like" comments, or denounce the authors of offensive comments - which is a way to fight, for example, racist posts, or acts of pedophilia on the internet. In order to access the comments section, users must register and have a login and password.

The possibility of audience participation raises naturally the key concepts of transmedia storytelling, systematized by Jenkins (2009b) in the opening conference of the Future of Entertainment convention, held at the Massachusetts Institute of Technology (MIT), in November 2009: spreadability vs drillability; continuity vs multiplicity; immersion vs extractability; worldbuilding; seriality; subjectivity and performance. For Souza (2011), these concepts are considered, at the same time, theoretical propositions and evidence of how the different transmedia franchises tell stories using different platforms and relying on the active participation of the public at various stages of the process, such as creation, circulation, or the search for and sharing of, information. Therefore, "the principles 
of NT symbolize a triple maturation: of the ideas of Jenkins [...], of producers and corporations that develop transmedia experiences, and of the public familiar with this form of storytelling" (SOUZA, 2011, p. 75).

According to Jenkins (2009b), spreadability refers to the ability of the public to actively participate in the circulation of media content through social networks and in the process of expanding its economic and cultural value. In analyzing this principle in the journalistic field, Souza (2011) explains that spreadability goes beyond the role of the audience in media circulation.

\begin{abstract}
The audience can expand access to a certain journalistic content when using the post-filters - tools and applications that promote a new selection of material and, therefore, a new cultural mediation. However, the phenomenon is broader than that. Spreadability is associated with transmediation and may occur when there is recommendation from other platforms, such as Facebook and Twitter. In summary, spreadability in journalism includes the use of recommendation, valuation, sharing and comments tools on the news sites, and the use of social networks with similar purpose. (SOUZA, 2011, p.149).
\end{abstract}

TV Folha uses at least two tools to recommend, namely Facebook and g+1, and nine tools for sharing: Twitter, Facebook, Orkut, RSS, Windows Live, MySpace, Google, Delicious and Digg. By clicking on the logos of these social networks, the public is redirected to the link of the article that they are viewing and can share it on their preferred platforms. In the same space, one can also follow the "Folha Multimedia" (name given to Folha.com, the site of the newspaper Folha de São Paulo, hosted on the UOL website) through Twitter and become a follower of the former, or visit "Folha de São Paulo" on Facebook and become a fan through the "like" section. With the FSP Facebook space, the public can also vote separately in the editorial sections of this news medium, participate in special offers and contests, and access their preferred news. That is to say, those who watch TV Folha on its website have access to other platforms and can spread the reports very quickly through recommendation and sharing.

Drillability concerns public engagement with the storytelling complexity and is associated with the concept of spreadability. However, as Jenkins writes (2009b), both principles can be built on the same transmedia franchise but represent different dimensions of that experience. He explains that there may be cases in which a franchise is characterized by spreadability without offering any real depth for drilling, but that it can also provide depth without encouraging spreadability by social networks. 
Jenkins (2009b) quotes Jason Mittell to explain that drillable programs encourage viewers to dig deeper to understand the storytelling and create what might be termed "engagement magnets", attracting viewers to the world of stories and urging them to deepen the information. In journalism, according to Souza (2011), this principle can be linked to the deepening and contextualization of news.

\footnotetext{
The more details a story has, the more "penetrable" it is. In journalism, drillability may be associated with deepening and contextualization. Deepening is the addition of information, details and versions. Context widening comprises the relationship, for example, with other news. In the digital environment, memory assumes both functions: to contribute to deepening and contextualization. Thus, studies conclude that memory is one way of providing drillability. (SOUZA, 2011, p.80)
}

In the case of the TV Folha editions under analysis, it is apparent that drillability may be associated with further contextualization of news and deepening of information. One example is the report from Fabiano Maisonnave (2012): "One year after the tsunami, starting over is still uncertain," shown at the beginning of the program. Various sources give eyewitness accounts of the tragedy, including residents of Sendai, the victims and the reporter himself. The wealth of details provided by the sources and the fact that the text leaves many questions unanswered allows the audience room to seek solutions, favoring drillability. Furthermore, the text produced by the same professional who writes a version for each medium (TV, printed and internet), leads audiences to appreciate their transmedia nature, which, however, is not evident from the scarcity of resources that lead viewers to other platforms to access more information.

As much as TV Folha's virtual page makes available the links 'issues of the day', 'breaking news', 'the latest news you have not read' '+ heard / seen' and the '+ sent ', it does not encourage the public to seek further information, or even internal sources, such as Grupo Folha's own collection. On the contrary, the links provided on TV Folha's website refer to several issues, which potentially might feature both in Folha de São Paulo, Folha Digital, on UOL or TV Folha itself, but are not presented as additional links to the news item. That is to say, there is no incentive for drilling into what could be called 'internal' drilling - nor for the 'outside' driling, since, on the TV Folha page, what is seen as external material by Grupo Folha is just banner ads.

Therefore, despite the collection of editions FSP has made available since 1994, the deepening and contextualization of TV Folha are 
subject to the interest of the public, who need to search by themselves, since no links to related or previous news are provided. Interestingly, there are no links to the text of the printed TV agenda either. Despite its convergent nature, TV Folha does not capture the drillability of NT however linked to spreadability.

Hence, TV Folha fails to take advantage of another aspect of transmedia storytelling: continuity vs multiplicity. In the fictional universe, this concept comprises the coherence and plausibility of the story and can lead to multiplicity of logic, for instance, a Spider Man movie can be understood as a continuation of the Marvel universe or as the Spider Man franchise (JENKINS, 2009b). In journalism, according to Souza (2011), this concept can be associated with at least two forms: the linkage between the information in a text and the relationships between news on the same topic.

\begin{abstract}
In the first case, the continuity of the text depends on the structure and on the second element connecting texts. In hypertext narrative, this connection can be made via the links. In light of a transmedia perspective, a third possibility needs to be considered: the linking of texts existing on different platforms. Thus, the link between the fragments of the story happens via transmediation and the result is a further understanding of the narrative. (SOUZA, 2011, p. 150).
\end{abstract}

Interestingly, even though the news broadcast on TV Folha originates in the newspaper, the topics and direction of which are the same, it does not always have links in its online version to connect the different media. Both vehicles could complement the storytelling, since the reports in them stem from the same topic and approach, but have different characters and texts. Despite the favorable context for continuity, TV Folha does not take advantage of this feature, not even internally. Even if one considers that continuity could occur from the links '+ heard / seen "and / or "+ sent," made available on the right side of TV Folha's web page, it would be in incomplete form, since it leads the public to the TV Folha text itself and not to that of FSP. So, there is no connection between TV storytelling and printed storytelling, which seems necessary to ensure there is proper transmedia continuity. Similarly, FSP teams need to produce transmedia content in printed, TV and internet, forms, with different texts and characters for each medium or, in case of repeated characters, with distinct portions of their testimonies.

In journalism, according to Souza (2011), multiplicity concerns the secondary stories or versions presented by journalists, and the alternative versions, presented to the public. However, this resource is also poorly exploited by TV Folha. For example, the article "Growing 
adhesion of parents to home education in the country is noted," by reporter Claudia Colluci, published in the Daily News section, with a citation on the cover of FSP on June 10, 2012, contains a small table in the middle of the text with the TV Folha logo and information on the program schedules with the following recommendation: "You can also watch this at folha.com and on UOL." This strategy can be understood as a reference to the television version of that report, but would it be enough to indicate the multiplicity of versions?

The space could also be used to promote the principles of spreadability, drillability and sense of continuity, but it is more reminiscent of an ad on TV Folha than an invitation for the public to watch the same item on television. Multiplicity is related to re-telling the story, distinguishing between business and the public, as explained by Souza:

\begin{abstract}
In the case of news corporations, multiplicity becomes important, as it is related to the exploitation of the story of a character presented in a report. In this case, a parallel universe is revealed. Regarding the public, multiplicity is associated with the recounting of the story, whether through versions that differ from those covered by the mainstream media, such as the reports that denounce inconsistencies, and independent media, or even the parodies of newscasts.(SOUZA, 2011 , p. 151).
\end{abstract}

In his analysis, Souza (2011) adds that the principle of continuity vs multiplicity is linked to what Jenkins (2009b) calls a unified experience. That is to say, the application of this principle causes the public to have the notion that all media products of an NT integrate a single story which is not apparent in the cases of FSP and TV Folha.

With regards to the concept of immersion vs extractability, Jenkins (2009b) explains that both refer to the perceived relationship between transmedia fiction and everyday experiences. While immersion is the consumer's ability to enter the world of the story, extraction involves drawing on aspects of the story, such as resources for spaces of everyday life - like movie theaters that emerged in the US in the 1920s, considered instruments of immersion because they provided fantastic environments to watch movies that were themselves, and the more contemporary amusement parks, such as the theme park that aims to reconstruct the world of Harry Potter or the Dubai theme park based on Marvel superheroes (JENKINS, 2009b). For Hayao Miyazki (apud JENKINS 2009b), immersion is the driving force behind the creation of the movie industry and has fueled the development of many subsequent means of communication. 
In transmedia storytelling, immersion relates to the highest levels of connection between the public and content. Based on the aforementioned conference of Jenkins, Souza (2011) argues that the use of images showing or simulating the third dimension, or the use of narrative formats allowing for the representation of the reader in the space of the narrative, would be ways to apply immersion to journalism. As a parameter, Souza (2011) adopts the following requirements in his research: dynamic material (with movement) that can be manipulated (which can be moved by the public) and / or with zoom resources. In the case of TV Folha, the dynamic nature of the video itself already satisfies the first requirement, and its exhibition on the internet can fill the screen partially or totally, thus guaranteeing the zoom features in the program as a whole, but not in a particular image. Manipulation, in this case, can be better associated with the font size of the texts, which can come in two sizes according to the internet user's preference.

In the texts produced for both TV Folha and FSP, it is also possible to identify another key concept of NT, that of the construction of worlds or universes. According to Jenkins (2009b), this concept appears to be closely linked to the principles of immersion and extractability, since both represent ways for consumers to engage more directly with the worlds represented in the narratives, treating them as real spaces that somehow intersect with our own realities. In fiction, this concept is linked to the launch of a world that can support multiple characters, stories and media - communicating worlds are constructed by interconnecting stories scattered in publications. In journalism, according to Souza (2011), presenting the world of the story in a news piece depends on what the narrative brings, the level of attention and cultural background of the reader. Therefore, world-building depends on the context.

This is evident in the aforementioned report by Claudia Colluci (2012), which contextualized the issue under analysis by referring to the Penal Code, the Law of Guidelines and Bases (LDB) and the Statute of Children and Adolescents (ECA), and through interviews with people for and against home education, not only parents, but also education professionals and a legislator. It is thus clear that the world-building of this story occurs in a contextualized way, with information about the law and arguments from each character.

Another key NT concept that can easily be identified on TV Folha is seriality. For Jenkins (2009b), the series creates parts of the story, scattering it into multiple portions that can be consumed in any order - due to the nonlinear nature of the transmedia entertainment 
experience. Therefore, according to the author, one can think of transmedia storytelling as a hyperbolic version of the series, where the pieces of information of the meaningful and engaging story are dispersed - not simply through various segments within the same medium, but in many media systems.

In light of the transmedia perspective, Souza (2011) argues that seriality can go beyond the link between parts of a program or the content of a theme aired on different days on the same platform, thus connecting parts of the story across multiple platforms. In the case of journalism, he adds, different forms of seriality are used to tell stories through special content or redeem a subject that continues to impact outcomes.

Because TVFolha also has its stories in print, it can be characterized by seriality through the perspective of transmedia. However, one must be careful not to confuse seriality with sense of continuity, since both make the connection between segments of the story. Therefore, as Souza makes clear (2011), while continuity refers to the continuation of the article on another platform, seriality is the relation between the part and the whole, and may be associated with patterns of repetition or recovery in order to connect segments of a story. Thus, it is not only about producing material in episodes but rescuing a subject that has had a certain impact, and presenting development - as the journalistic suite, which provides a brief contextualization of a subject without rescuing the whole story.

On TV Folha, it can be argued that seriality is also present in guided subjects, even if the case being addressed is approached differently. For example, the issue of drugs and neglect of public money are recurrent themes, as well as security problems, fear of violence in São Paulo, and the cultural contexts.

The principle of subjectivity refers to the different ways of telling stories, which may make possible different experiences. For Jenkins (2009b), the focus on multiple subjectivities is giving rise to the use of Twitter as a platform through which fans or authors can develop stories about the secondary characters and their responses to events represented in the main text. Souza (2011) highlights that, in the main, the formats of contents that do not merely copy or adapt existing models in print and audiovisual media are assessed, as well as the existence of different ways to narrate, or the presentation of different perspectives on the narrative. 
to changes in the mode of narration (RYAN, 2009), such as the use of the first person. Format change contributes to enhancing the understanding of the narrative. In this sense, one refers to Salaverría (2009). The author says that journalism in digital media needs to explore new formats and not apply formats from other platforms. Thus, we intend to identify ways of narrating and narrative formats that enrich modes of storytelling. (SOUZA, 2011, p. 154).

In television journalism nowadays, there seems to be a clear trend towards informality, as exemplified by TV Folha. Reporters and columnists express clearly their opinions and worldviews in rather colloquial fashion and impart a more personal type of content to the news story, as the format changes depending on the medium. By rejecting the traditional video passage and recording a testimonial to the same aesthetic standards as their sources, recounting what was seen and felt when making the report, the reporter takes viewers to the making-off style adopted in documentaries and series. This is a way to tell the story that enriches it and encourages public participation, through discursive informality and humanization of the reporter.

Incidentally, encouraging public participation raises another NT principle: performance, which, according to Jenkins (2009a), motivates the audience (cultural attractors) for a particular purpose (cultural activators). The author adopts the concept of cultural attractors formulated by Pierre Lévy (apud JENKINS, 2009a) to refer to the ways fans and critics coalesce around texts regarded as valuable opportunities to construct meanings and evaluations, and formulate their own concepts of cultural activators to refer to the texts that act as catalysts, triggering a process of shared construction of meanings.

Jenkins (2009b) explains that cultural attractors bring together a community of people with common interests and activators give something for the community to produce, inducing the public to make their own contributions. Therefore, he adds, more and more producers are being asked to think about what the fans will do with their series and design spaces for their active participation. Among the observation requirements for these two concepts, Souza (2011) adopts the sections intended for public participation and the ways journalistic products challenge the audience to participate in these sections. On TV Folha, following this line of observation, tools to recommend, share, enjoy and send material by email can be considered cultural attractors of performance. Public participation in the comments section, where users can give opinions, criticize and praise, can be seen as a cultural activator to check, at least, the public's interest on a particular subject. On TV 
Folha, as mentioned above, some themes are recurrent and this can be considered an indicator of performance, the importance of which is essential to verify the production of contents from viewer activities.

\section{Final Considerations}

During this analysis, the presence of the basic concepts of transmedia storytelling on TV Folha were identified, though some have yet to be used fully. By bringing together, simultaneously, the printed, internet and audiovisual television components, TV Folha moves easily across different platforms and reinforces its transmedia potential. However, as explained before, it has not been maximized.

For example, the article from June 10, 2012: "Growing adhesion of parents to home education in the country is noted," has many more characters, details and information in the printed versions, compared to the television report and, thus, it unfolds in two FSP texts. The second text was entitled "In the case record-holder city, 'moral values' is the explanation." The sources of the printed texts feature in the television text but the statements are not repeated. Speech excerpts are cut out from interviews that are re-contextualized in each text. This example illustrates perfectly the concept advocated by Vizeu (2005) and others, that news is a fragmented representation of reality. Further, taking excerpts of distinct testimonials suggests the transmedia nature of the product.

The article by columnist Clovis Rossi from April 8, 2012, also reflects this quality. Entitled 'Clovis Rossi looks into Dilma's trip to the U.S' on the TV Folha website, and 'Neither wagging the tail nor barking' in Folha de São Paulo, the text discusses the relationship between Brazil and the United States, but is vastly different from one medium to the other. While in the printed version Rossi makes a historical contextualization to conclude that the relationship today has matured, on TV Folha he draws attention to what could disrupt this relationship, stating that only agendas concerning Iran and the World Bank presidency would cause unease between the two powers. At 1'59" in length, the television text was introduced via a television miniclip with dynamic short track images of the columnist preparing to record in a making-off style. When he starts talking, his text is interspersed throughout with photographs, a format that reminds viewers of the participation of TV news commentators.

This construction leads to reflection on the impact of hybridization processes in visual journalism. The paradigm of convergence provides 
the interaction between old and new media and promotes transmedia capability, requiring more skill, creativity and knowledge from the professionals in journalism. The NT allows journalists to decide on how to use each medium, drawing on what is best in each.

The multifaceted character of the "digital age" allows for modernizing the ways of narrating a story, providing a much more dynamic and multimedia-related workflow through the convergence of different media. For example, TV Folha makes use of songs that make reference to the subject matter of a stronger trail to give dynamism to the issue. Another feature is the variety of visual effects. In the aforementioned article about the tsunami in Japan, the issue deployed the fast effect edition used to indicate the passage of time, and made simultaneous use of photographs of the same place today and a year ago, when the disaster took place. They are still and moving images that intersect, adopting the documentary style.

Thus, TV Folha shows that convergence media deeply affect the language, narrative and aesthetics of audiovisual journalism and alter professional profiles and routine production processes. Inevitably, these changes affect ethics in the profession, bringing about $/ 0\}$ new reflections and discussions. They also affect the relationship with the public, who are now more participatory. Transmedia storytelling allows for a high degree of involvement from the public, who can take an active role in the process, and move on from passive reception. It all depends on the strategies of each product and/or medium used to explore this new reality. Despite its modern content production proposal and importance in building a new paradigm, paper TV has not yet made full use of its convergent potential and transmedia capabilities which, in turn, represent a real cultural transformation as the public is encouraged to make connections between dispersed journalistic content, thus revolutionizing the way society communicates, is informed and acts. 


\section{$I_{\text {NOTES }}$}

1. Nave is a project of Oi Futuro oriented towards the research and development of educational solutions by using information and education technologies and which was included in the "Microsoft Innovative Schools", making up a list of the 30 best schools in the world in this area.

2. Conducted by Marcus Tavares, this interview explains that Transmedia Storytelling is also the name of a course at the Massachusetts Institute of Technology (MIT) and its goal is to "empower creators / storytellers, in many different media formats, to develop strategies and content involving the public in a unique way: combining the best elements communication platforms have to offer, but never forgetting the power of a good story."It was published in the Pontocom magazine and on the website Press Observatory.

3. Alysson Martins refers to Luiza Lusvarghi, who mentioned that the concept of crossmedia arose in the field of advertising and marketing through the "possibility of the same campaign, company or product using simultaneously different types of media: printed, TV, radio and the internet" (LUSVARGHI , 2007, p. 2 apud MARTINS, 2011, p. 20), and indicates other media to the public, inviting viewers, for example, to access the website for more information.

4. By classifying and differentiating models adopted by virtual news broadcasting, Neusa Amaral (2007, p. 8) states that on-demand transpositive model products "are placed on menus on demand, and internet users access them according to their own time and interest. They are able to access them however often and whenever they want."

5. The goal here is not to delve into the merits of this argument, though it is considered important. For further information, please consult the following texts: "TV Cultura em debate na Assembleia Legislativa de SP", "TV Folha: Uma unanimidade", and "TV Cultura and TV Folha: a destruição do caráter público de uma emissora" (Bia Barbosa), with details in the references.

\section{REFERENCES}

AMARAL, Neusa Maria. Televisão e Telejornalismo: modelos virtuais. In: CONGRESSO BRASILEIRO DE CIÊNCIAS DA COMUNICAÇÃO, 30, 
2007, Santos, SP. Resumos... Available at: <http://www.intercom. org.br/papers/nacionais/2007/resumos/R2233-1.pdf>. Accessed on: 13 May 2012.

BARBOSA, Bia. TV Cultura e TV Folha: a destruição do caráter público de uma emissora. Observatório do Direito à Comunicação, 31 May 2012. Available at: <http://www.viomundo.com.br/falatorio/biabarbosa-tv-cultura-e-tv-folha.html>. Accessed on: 19 June 2012.

BIEGING, Patrícia; BUSARELLO, Raul; ULBRICHT, Vania. Reflexões sobre subjetividades do produto cultural Hannah Montana. In: CONGRESSO PANAMERICANO DE COMUNICAÇÃO, 2010, Brasília, DF. Available at: <http://www.ipea.gov.br/panam/pdf/GT2_Art4_Patr.pdf>. Accessed on: 13 June 2012.

CARVALHO, Nathália. 'TV Folha' estreia na Cultura com destaque para colunistas e 'links' com matérias do impresso. Portal Comunique-se, São Paulo, 12 mar 2012. Available at: <http://portal.comunique-se. com.br/index.php?option=com_content\&view=article\&id=681 87:tvfolha-estreia-na-cultura-com-destaque-para-colunistas-e-links-commaterias-do-impresso\&catid=28: carreira\&ltemid $=20>$. Accessed on: 08 Apr. 2012.

COLLUCI, Cláudia. Cresce adesão dos pais ao ensino domiciliar no país. Folha de São Paulo, São Paulo, 10 June 2012. Cotidiano, C8.

DINIZ, Talita Rampazzo. (In) conclusões sobre a narrativa transmídia no jornalismo: sobre o que pode ser e o que se deseja. In.

CONGRESSO DE CIÊNCIAS DA COMUNICAÇÃO NA REGIÃO NORDESTE, 13, 2011 , Maceió, AL. Resumos... Available at: <http://intercom. org.br/papers/regionais/nordeste2011/resumos/R28-0833-1.pdf>. Accessed on: 18 June 2012.

DORES, Kelly. TV Folha mira diferenciação e público jovem. Jornal Propaganda e Marketing, São Paulo, 26 Mar. 2012. Available at: <http://propmark.uol.com.br/midia/39912:tv-folha-miradiferenciacao-e-publico-jovem>. Accessed on: 13 May 2012.

DÓRIA, Tiago. Transmídia pode ser aplicada ao jornalismo. Tiago Dória Weblog: doses diárias de cultura digital, tecnologia e mídia, 2010. Available at: <http://www.tiagodoria.ig.com.br/2010/02/05/ transmidia-pode-ser-aplicada-ao-jornalismo>. Accessed on: 19 June 2012 ,

ESTREIA do "TV Folha" eleva a audiência da TV Cultura. Folha Digital, São Paulo, 12 Mar. 2012. Available at: <http://www1.folha.uol. com.br/multimidia/videocasts/1060589-estreia-do-tv-folha-eleva-aaudiencia-da-tv-cultura.shtml>. Accessed on: 08 Apr. 2012

FOLHA estreia programa na TV em março; veja vídeo. Folha Digital, São Paulo, 29 Feb. 2012 . Available at: <http://www1 folha.uol.com. $\mathrm{br} /$ multimidia/videocasts/1055001-folha-estreia-programa-na-tv-em- 
marco-veja-video.shtml>. Accessed on: 13 May 2012.

JENKINS, Henry. Cultura da Convergência. Translation: Susana Alexandria. 2 ed. São Paulo: Aleph, 2009a.

Revenge of the Oragami Unicorn: Seven Core

Concepts of Transmedia Storytelling. Confessions of an Aca, 2009b. Available at: < http://www.henryjenkins.org/2009/12/the_revenge_ of_the_origami_uni.html>. Accessed on: 29 Aug. 2012.

JORNALISMO é aposta de reforço da Tv pública. Observatório da Radiodifusão Pública na América Latina, 14 Mar. 2012. Available at: <http://www.observatorioradiodifusao.net.br/index. php?option=com_content\&view=article \&id=847: jornalismo-e-apostade-reforco-da-tv-publica\&catid=50:destaques\&ltemid=366>. Accessed on 18 June 2012 .

KACHANI, Morris. Folha na TV. Folha de São Paulo. São Paulo, 11 Mar. 2012. Ilustrada, E1.

MAISONNAVE, Fabiano. Um ano depois de tsunami, recomeço ainda é incerto'. Folha de São Paulo, São Paulo, 11 Mar. 2012, Mundo, A20.

MARSHAL, Mclhuan. Os meios de comunicação com extensões do

homem. Translation: Décio Pignatari. 4ª ed. São Paulo: Cultrix, 1974.

MARTINS, Allysson Viana. Experiência das Narrativas Cross e Transmidiáticas no Webjornalismo. LOGOS Comunicação e

Sociedade - Estatuto da Cibercultura no Brasil. Rio de Janeiro, v.34, ano $18, \mathrm{n} \mathrm{01}, 1^{\circ}$ sem 2011 . Available at: <http://www.logos.uerj.br/ PDFS/34/02_logos34_martins_experiencias_narrativas.pdf $>$. Accessed on: 29 June 2012.

PERNISA JR, Carlos. Jornalismo Transmidiático ou Multimídia? In: CONGRESSO BRASILEIRO DE CIÊNCIAS DA COMUNICAÇÃO, 33, 2010, Caxias do Sul. Available at: <http://www.intercom.org.br/papers/ nacionais/2010/resumos/R5-1472-1.pdf>. Accessed on: 18 June 2012.

PERNISA JR; ALVES, Wedencley. Comunicação Digital - jornalismo, narrativas, estética. Rio de Janeiro: Mauad X, 2010.

ROSSI, CLÓVIS. Nem abanar o rabo nem latir. Folha de São Paulo, São Paulo, 08 Apr. 2012. Mundo, A20.

SOUZA, Maurício Dias; MIELNICZUK, Luciana. Aspectos da narrativa transmidiática no jornalismo da revista Época. Revista Comunicação e Inovação. São Caetano do Sul, v. 11, n. 20, 2010. Available at: <http://seer.uscs.edu.br/index.php/revista_comunicacao_inovacao/ article/view/947>. Accessed on: 29 June 2012. 
SOUZA, Maurício Dias. Jornalismo e Cultura da Convergência: a narrativa transmídia na cobertura do caso cablegate nos sites El País e Guardian. Dissertation (Master of Communication). Universidade Federal de Santa Maria. Santa Maria, 2011.

TAVARES, Marcus. Transmídia: a narrativa da atualidade.

Pontocom - a revista da mídiaeducacao. 07 Sept. 2009. Available at: <http://www.revistapontocom.org.br/edicoes-anterioresentrevistas/transmidia-a-narrativa-da-atualidade $>$ e <http://www. observatoriodaimprensa.com.br/news/view/transmidia_a_narrativa_ da_atualidade>. Accessed on: 19 June 2012.

TV Cultura em debate na Assembleia Legislativa de SP. Observatório da Radiodifusão Pública na América Latina, 8 June 2012.

Available at: <http://www.observatorioradiodifusao.net.br/index. php?option=com_content\&view=article\&id=952:tv-cultura-em-debatena-assembleia-legislativa-de-sp\&catid=50:destaques\&ltemid=366>. Accessed on: 20 Sept. 2012.

TV FOLHA: Uma unanimidade. Sul 21, Porto Alegre, 31 May 2012. Available at: <http://www.sul21.com.br/jornal/2012/05/tv-folhauma-unanimidade>. Accessed on: 20 June 2012. 